811.163.41'373.21

091=163.41"13"

https://doi.org/10.18485/sj.2021.26.1.17

ОЛГА И. БОГУНОВИТ *

Универзитет у Београду

Филолошки факултет
Оригинални научни рад

Примљен: 10. 11. 2020.

Прихваћен: 12. 1. 2021.

\title{
СТСРП. ос(ь)дьннКь: ТВОРБЕНО-СЕМАНТИЧКА И МОТИВАЦИОНА РЕКОНСТРУКЦИЈА
}

У раду се анализирају творбено-семантичке одлике стсрп. топонима ос(ь) льннкь забележеног у хрисовуљи српског краља Милутина и хрисовуљи бугарског цара Константина I Асена Тиха манастиру Св. Ђорђа код Скопља. На основу спроведене творбено-семантичке анализе датог топонима, те и у тежњи да се приближимо његовој примарној мотивацији, изнећемо хипотезе о мотивационим моделима које претпостављене творбене формације одражавају. Разматрани топоним проматраћемо најпре у ужем, а потом и у ширем лингвогеографском контексту. Претпоставку према којој се доњополошки топоним ос(ь)льннкь доводи у етимолошку, те и мотивациону везу са псл. им. *os(b)la 'брус, тоцилни камен (тоцило)', према спроведеној етимолошко-ономасиолошкој односно творбено-семантичкој анализи, издвојићемо као најверодостојнију.

Кључне речи: историјска топонимија, историјска оронимија, старосрпски, мотивациона реконструкција, Полог.

\section{1. ПРЕДМЕТ И ЦИЉ РАДА}

Основни предмет нашег истраживања чине творбено-семантичка и мотивациона реконструкција стсрп. топонима ос(ь)льннкь забележеног у Хрисовуљи краља Стефана Уроша II Милутина манастиру Св. Борђа код Скопља и Хри-

*olgabogunovic.94@gmail.com 
совуљи бугарског иара Константина Асена манастиру Св. Ђорђа код Скопља. Полазећи од текстуалног контекста у коме се разматрани топоним јавља, пажњу ћемо најпре посветити његовим гласовно-графијским ликовима, као и забележеној парадигматској структури. Захваљујући другим значајним подацима које дати текстуални контекст нуди - као што су назвања и топографска одређења суседних објеката, те њихово повезивање у ширу смисаону целину - изнећемо претпоставку о његовом топографском одређењу, будући да у самом тексту изостаје. Централни део рада чиниће творбено-семантичка анализа стсрп. топонима ос(ь)дьннкь, путем које ћемо отворити питање реконструкције његове претпостављене примарне мотивације, ослањајући се при томе не само на податке које пружа ужи већ и шири лингвогеографски контекст. ${ }^{1}$

\section{2. О КОРИШЋЕНИМ ИЗВОРИМА}

Стсрп. топоним ос(ь)цьннкь, чијом ћемо се творбено-семантичком структуром и претпостављеном примарном мотивацијом у овом раду бавити, посведочен је у хрисовуљама манастиру Св. Ђорђа код Скопља као међник доњополошког села рьчнцє, које је овом манастиру даровао још његов ктитор византијски цар Роман III Аргир (1028-1034). Његове дарове потврђивали су доцнији византијски, бугарски и српски средњовековни владари под чијом је влашћу својевремено била Скопска област. У хрисовуљи бугарског цара Константина I Асена Тиха и хрисовуљи српског краља Милутина имена претходних дародаваца експлицитно су поменута. Међутим, хрисовуље њихових претходника нису сачуване.

Хрисовуља краља Стефана Уроша ІІ Милутина манастиру Св. Ђорђа код Скопља, како оригинал није очуван, позната нам је на основу три фрагмента која се чувају у Архиву манастира Хиландара. Фрагмент А чини уводни део хрисовуље, док фрагменти Б и В (који се делимично поклапају) представљају њен продужетак и завршни део. Топоним који је предмет нашег рада забележен је у оквиру фрагмента В. ${ }^{2}$ Приликом његове анализе служићемо се приређеним издањем ове хрисовуље у првој књизи Зборника средњовековних ћириличких повеља и писама Србије, Босне и Дубровника (1186-1321) (в. ЗСПП: 315-333), као и фотографијама ове хрисовуље из Архива САНУ (АСАНУ) под ознаком 7903-а/6а, б, в, г. ${ }^{3}$ Оригинал Хрисовуље бугарског иара Константина Асена манастиру Св. Ђорђа код Скопља очуван је и налази се у Архиву манастира

${ }^{1}$ Описани поступак творбено-семантичке и мотивационе реконструкције који ћемо у раду спровести заснива се на теоријско-методолошким принципима А. Ломе примењеним у анализи топонимије Бањске хрисовуље (в. Лома 2013).

23а фрагмент В претпоставља се да је настао у периоду 1365-1375. године (ЗСПП: 316).

${ }^{3}$ Више о постојећим издањима разматране хрисовуље в. у ЗСПП: 315-316. 
Хиландара. За потребе овог рада служићемо се издањем ове хрисовуље приређеном у претходно поменутом зборнику (в. ЗСПП: 253-258). ${ }^{4}$

\section{1. Графијско-гласовне одлике и парадигматска структура разматраног топонима у датом текстуалном контексту}

\section{1) Одломак из Хрисовуље краља Стефана Уроша II Милутина манастиру} Св. Ђорђа код Скопља у коме су описане границе средњовековног полошког села рьчнце:

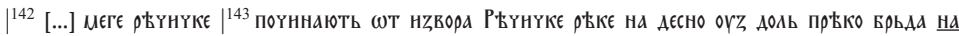

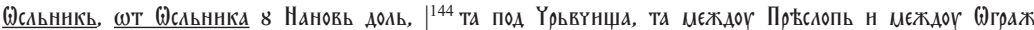

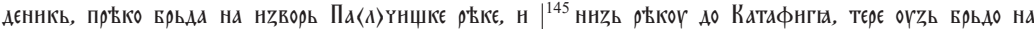

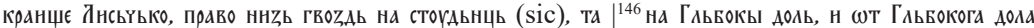

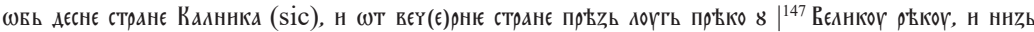

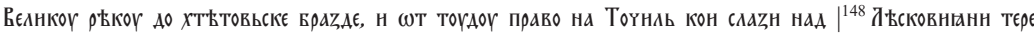

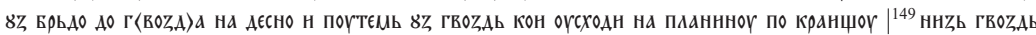

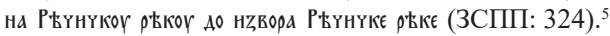

У анализираном фрагменту, што очитује и наведени одломак, танко јер се прилично доследно бележи у финалној позицији (нпр. на крају облика номинатива и акузатива једнине именица мушког рода). У осталим позицијама у којима се полугласник неколико векова раније изгубио танко јер се бележи само по изузетку. И када се у тим позицијама јави, то буде најчешће на морфемским спојевима речи: основа + суфикс $\left({ }^{73}\right.$ үрћшєвьскє, ${ }^{74} \Gamma(0) с п(0)$ дьствоүющниь, $\left.\right|^{79}$ водьньске (: $\left.\right|^{88}$ воденске), $\left.\right|^{82}$ варовьско, $\left.\right|^{89}$ прТсьҮке $)$, односно префикс + основа $\left(\left.\right|^{149}\right.$ нұьлаzн, $\left.\right|^{160}$ нұьвьнь). Омега се у речима словенског порекла најчешће јавља у иницијалној позицији.

У датом текстуалном контексту разматрани топоним јавља се у два граматичка облика: у акуз. јд. са предлогом на (на (Ө)сьннкь) и у ген. јд. са предлогом од ( основни облик (ном. јд.) једнак је посведоченом облику акузатива.

2) Одломак из Хрисовуље бугарског иара Константина Асена манастиру Св. Ђорђа код Скопља у коме су описане границе средњовековног полошког села рьчнце:

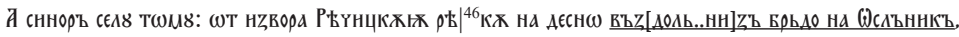

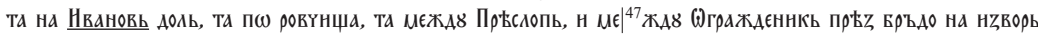

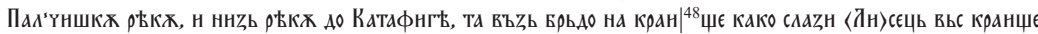

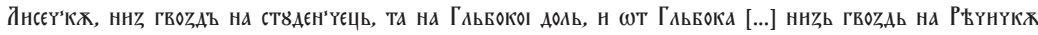
рtКкх А[0] нұвора єєж (ЗСПП: 256).

${ }^{4}$ Више о оригиналу и претходним издањима ове хрисовуље в. у ЗСПП: 253.

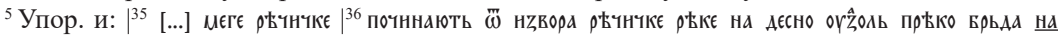

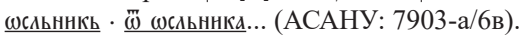


Као и у претходној хрисовуљи, и у овој се јер прилично доследно бележи у финалној позицији, с тим што је, поред танког јер, у употреби и дебело. У осталим позицијама у речи где се полугласник у говору изгубио јерови се бе-

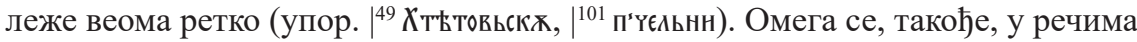
словенског порекла најчешће везује за иницијалну позицију, али се неретко сусреће и у унутрашњости речи. У овој хрисовуљи разматрани топоним забележен је само у акуз. јд. са предлогом на (на Юскъннкъ).

Уважавајући посведочене гласовно-графијске ликове и истовремено следећи тенденције рашког правописа, у раду ћемо разматрани топоним бележити у графијском лику са танким јеровима. На то да у загради бележимо још једно јер утицале су гласовно-графијске одлике могућих хомонимних паралела потврђених у ширем лингвогеографском контексту (упор. нпр. одредницу осьдьннкь у Даничићевом Рјечнику из књижевних старина српских (РКС: II, 243 s. v.)). Иницијално $o$, које је у изворима записано омегом, бележићемо графијски неутралнијом графемом 0.

\section{2. Топономастички контекст и топографско одређење}

стсрп. ос(ь) цьннкь

Хрисовуље из 13. и 14. века - будући да баштине прецизне податке о дарованим поседима, те и о њиховом омеђењу - драгоцен су и незаобилазан извор у проучавању (старо)српског и уопште словенског именослова. У улози међника најчешће су, нарочито ако је област брдско-планинска, лако уочљиви и међусобно јасно издиференцирани облици рељефа попут планина, брда, брежуљака, врхова (односно глава), гребена, превоја, литица, стена, стрмина, страна, долина/долова, пољана, пашњака, шума, и сл. (Божанић 2011: 117-118; в. и Пурковић 1940, Мишић 2007). Будући да су непомични и да у већој или мањој мери успешно одолевају зубу времена, водећа улога таквих облика рељефа у омеђивању средњовековних територија у потпуности је оправдана, те нас обилата заступљеност оронима (потом и хидронима) у повељама односно хрисовуљама не изненађује.

Из текстуалног контекста у коме се разматрани топоним јавља не дознајемо његово топографско одређење, те нам је - с обзиром на то да о њему не налазимо помена у каснијим историјским изворима, као ни на консултованим географским картама - отежано да га реконструишемо. ${ }^{6}$ Насупрот томе,

${ }^{6}$ Истини за вољу, једино Ј. Трифуновски у својој антропогеографској студији о Пологу, наводећи границе средњовековног села Речице, „Осленик” одређује као брдо: „Граница је почињала од извора Речичке реке, затим је водила на десно преко брда Осленик [подвукла О. Б.], па на Јованов дол" (Трифуновски 1976: 371). Границе овог села он наводи позивајући се на хрисовуљу бугарског цара Константина Асена манастиру Св. Ђорђа код Скопља приређену од стране Ј. Иванова (1970) и на хрисовуљу српског краља Милутина истом манастиру приређену 
њему суседни нановь доль помиње се у Хрисовуљи краља Стефана Душана Хтетовском манастиру (1343. год.) као планина 'планински пашњак'7 коју је краљ Душан даровао овом манастиру: Н вндъ кралєвьст’во мн црьквь Светоүю

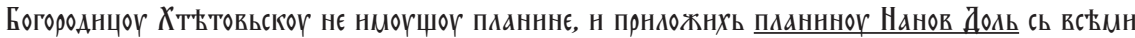

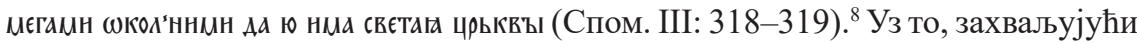
карти коју је Р. Грујић (1933: 35) приложио у свом раду о полошко-тетовској епархији, дознајемо да пашњачки предео ндновь доль територијално припада шарпланинском комплексу северозападно од Тетова.

Средњовековном селу рьчнцє - чији је вероватно најсеверозападнији међник био нановь доль, а у чијој је близини и разматрани ос(ь)льннкь - данас одговарају два села југозападно од Тетова - Голема Речица (јужније; на 470 мнв) и Мала Речица (ближе Тетову, те се може сматрати његовим предграђем; на 460 мнв), оба са претежно албанским становништвом. Судећи по наведеном, северна граница средњовековног села рьчнцє протезела се даље од данашње територије тетовских села Големе и Мале Речице. Међна линија овог средњовековног села, као што се види из наведеног одломка, претежно је валовита, сачињена од брда и других узвишења која се смењују са доловима односно планинским пашњацима. Руководећи се разматраним текстуалним односно топономастичким контекстом (илити сликом природне целине коју на основу њега стичемо) - можемо претпоставити да је именом ос(ь)иьннкь највероватније означено какво истакнуто узвишење, планински превој односно „дел”, врх или упадљива стена. Другим речима, можемо претпоставити да је реч о орониму.

\section{3. ТВОРБЕНО-СЕМАНТИЧКА АНАЛИЗА И МОТИВАЦИОНА РЕКОНСТРУКЦИЈА}

О етимологији доњополошког оронима ос(ь)льннкь, према нама познатој и доступној научној литератури, писала је једино љ. Станковска (1983: 272, s. v. ОСЛЕНИК) у склопу своје докторске тезе Македонскиот топонимски систем до XVI век. ${ }^{9}$ Према поменутој ауторки, ороним ос(ь)цьннкь може се довести у етимолошку везу са: 1) псл. им. *osblъ 'магарац' (упор. стсл. осьлъ, стсрп. осьљь) и са 2) псл. им. *os(b)la 'брус, тоцилни камен (тоцило)' (упор.

од стране Р. Грујића (1936). Међутим, према нашем увиду у наведена издања, не можемо се пак безрезервно сложити са таквим одређењем: упор. нндъ Брьдо на ()слъннгкь - та на Нвановъ доль (Иванов 1970: 583), као и прько қрьда на Осльннкь (!), Фт' Фсльннка в Нанов' Поль (Грујић 1936: 15).

${ }^{7}$ Првобитно значење псл. дијалектизма *polnina било је 'високопланински пашњак' и оно је у Хрисовуљи краља Стефана Душана Хтетовском манастиру (1343. год.) очувано, док је савремено значење им. планина 'mons' секундарно (в. Лома 2013: 171, s. v. ПЛАНИНА).

${ }^{8}$ В. и Копривица 2014: 151.

${ }^{9}$ Грађом докторске тезе Љ. Станковске обухваћене су и хрисовуље манастиру Св. Ђорђа код Скопља. 
стсл. осла, цсл. осьла). У дубљу етимолошко-ономасиолошку расправу ауторка се није упуштала.

Како бисмо се приближили изворном значењу топонима и његовој примарној мотивацији, најпре морамо размотрити његову творбено-семантичку структуру - условљену ,унутарјезичким законитостима (тј. постојањем специфичних топонимијских образаца)” (Вучковић 2017: 113), односно „морамо га најпре сврстати у неку творбену категорију, одређену како формално - начином образовања, тако и функционално, пре свега на основну дихотомију посесиви / дескриптиви” (Лома 2013: 17). Зато ћемо се најпре посветити питању посведочености и продуктивности претпостављене мотивационе односно творбене основе и творбеног суфикса на датом синхроном језичком пресеку, затим изнети хипотезе о мотивационим моделима које ове творбене формације одражавају и уједно их преиспитати.

1) Оронимијска формација ос(ь)цьннкь могла је настати суфиксалном универбизацијом примарне синтагматске номинације чији је зависни члан био исказан придевом изведеним суфиксом -bnъ: упор. **ос(ь)льнн Аьль / врьгъ и сл. Топоними такве творбене структуре на синхроном пресеку од краја 12. до почетка 14. века честа су појава. Према нашем увиду у старосрпску грађу тог периода (ЗСПП: 585-609), међу њима су неретко они чија је придевска основа изведена од фитонима: упор. Хвонннкь (: псл. им. *xvoja/*xvojb 'врста четинара (бор, клека и сл.); иглица'), Брєсннгь (: псл. им. *berstъ 'дрво брест (Ulus)', упор. и Бръстннца), Смрьч'ннкь / Смрнучнннкь (: псл. им. *smerka 'смрча (Picea abies); клека (Juniperus)'), и сл.; затим они топоними чија је основа изведена од назива за природни елемент: нпр. Рвдннкь / Роүдннкь ( $\longleftarrow$ *rudbnъ(jb) (: псл. им. *ruda) bergz и сл.), као и они чија придевска основа не потиче од именице, већ од глагола: упор. ороним Ког'ннкь, планину на Косову која и данас носи то име. Како истиче А. Лома (2013: 109, s. v. КОЗНИЦЕ), топонимска основа kozn(позната широм (старо)српског подручја) ${ }^{10}$ потиче од псл. прид. *kozbnъ(jb) „‘који је у вези са козењем, тј. парењем и размножавањем (дивљих) коза', са нијансом значења 'тешко приступачан, врлетан'" - изведеног не од им. *koza, већ од глагола *koziti se 'размножавати се (о козама)'. Као што је познато, а на шта на истом месту подсећа истакнути аутор, придеви са суфиксом -ьпь ретко настају од зоонимске основе, те их је на прасловенском нивоу могуће реконструисати само по изузетку (упор. псл. *komarbnb(jb)), *kon'bnb(jb), *rybbnz(jb)) (Исто). Другим речима, топонимска основа kozbn- не може бити од прид. **kozbnъ(jb) 'козји' будући да придев изведен суфиксом -ьnъ од им. *koza у прасловенском није могуће реконструисати.

${ }^{10}$ Топонимска основа $k o z b n$ - карактеристична је за средишњу јужнословенску територију (в. Лома 2013: 109, s. v. КОЗНИЦЕ). 
Како придеви са суфиксом -ьпъ од зоонимске основе постоје само по изузетку, те и како за прасловенски није реконструисан придев **oslbnъ(jb) 'магарећи' (в. ECCJA 36; Дерксен 2008) - претпоставка да основа os(b)lbnпотиче од псл. им. *osblъ 'магарац' губи поуздан историјскојезички ослонац.

2) Претпоставку по којој се у номинационој основи разматраног оронима налази им. *os(b)la 'брус, тоцилни камен (тоцило)' - са становишта његове творбено-семантичке анализе - могли бисмо сматрати оправданом. Иако за прасловенски период није реконструисан ни придев **os(b)lbnъ(jb) 'брусни' (в. ЕССЈА 36; Дерксен 2008), познате творбене законитости не поништавају могућност његовог постојања (упор. нпр. синонимну им. *brusъ и од ње изведен придев *brusbnъ $(j b))^{11}$. Зато би се претпоставка по којој је оронимијска формација ос(ь)льннкь настала суфиксалном универбизацијом могла, са извесном резервом, узети као веродостојна. Примарно мотивационо значење доњополошког оронима ос(ь)גьннкь - уколико пођемо од тога да је изведен од придевске основе $o s(b) l b n-(:$ псл. им. *os(b)la) 'брус, тоцилни камен (тоцило) '), тј. да је образован суфиксалном универбизацијом - могло би се дефинисати као 'површина (брег, дел и сл.) прекривена оштрим каменом, оним каменом од кога је могуће израђивати брусеве или који је налик таквом'. Међутим, не би било неосновано ни претпоставити да је за такву номинацију био пресудан облик означеног рељефног објекта који би, вероватно због своје изразите зашиљености при врху, номинатора могао подсећати на ослу.

Када је у питању са̂м творбени образац, у оквиру разматране хипотезе не смемо искључити ни могућност да разматрани ороним није образован од придевске основе суфиксалном универбизацијом, већ од именичке основе $o s(b) l$ - на коју је додат сложени суфикс -ьnikъ или пак онимизацијом апелативног деривата **os(b)lbnikъ. Сложени суфикс -bnikb, наиме, већ је на стсл. нивоу почео функционисати као самостални творбени елемент, што потврђује постојање стсл. именица изведених од основа које нису пореклом од придева на -ьпъ: уПор. нПр. ПьнАжьннкъ (: им. пьнАъь) (в. Јефимова 2006: 42, 48-49). У кругу именичких изведеница са предметним значењем тај суфикс је на старословенском нивоу био изразито продуктиван (упор. нсточьннкъ, отрочьннкъ 'незрели грозд', потрьпальннкъ, скждьльннкъ, свьтнльннкъ и др.), а доказ његове изразите продуктивности у сфери именичких изведеница било је и учешће у творбеним типовима које карактерише удвојена афиксација, тј. оним где се овај суфикс јавља као секундарни творбени афикс додат било на безафиксну творбену основу (упор. ровъ : ровьннкъ), било на основу већ изведену неким примарним творбеним афиксом (упор. потрьпало : потрьпальннкъ). Улога наре-

${ }^{11}$ Псл. именице *os(b)la и *brusъ припадају старијој словенској терминологији, док је псл. термин *točidlo, како истиче О. Трубачов, повезан са млађом техником ковања и оштрења (Трубачов 2008: 753). 
ченог суфикса у овим творбеним типовима није до краја јасна будући да се творбено значење овим поновљеним творбеним актом није битно мењало. ${ }^{12}$ Сама творбена појава могла би ићи у ред оних које Р. Бошковић, без ширег објашњења, назива „суфиксални узус епохе”, ${ }^{13}$ а што се односи на појаву неких продуктивних суфикса у функцији маркера припадности датог деривата одређеној лексичко-граматичкој односно твобеној формацији. Таквом типу творбеног односа могао би припадати и стсрп. однос **oc(ь)גa : ос(ь)גьннкь - при чему би дати суфикс могао имати функцију индивидуације, односно диференцијације датог географског објекта од групе околних објекта са сличним карактеристикама.

Континуанти псл. им. *os(b)la 'брус, тоцилни камен (тоцило)' забележени су у већини словенских језика, како у њиховој историји тако и на савременом нивоу (в. ECCJA 36: 84-85, s. v. *os(b) la). ${ }^{14}$ Изузетак су једино савремени јужнословенски језици будући да су континуанти ове именице широко заступљени само у словеначком језику. У постојећим историјским речницима српског језика (РКС, РЈАЗУ), као и у речницима савремених српских дијалеката (према нашем увиду у њих $)^{15}$ - они нису забележени ни у самосталној употреби ни у виду својих деривата, бар кад је реч о апелативној лексици.

У Мажуранићевом речнику Prinosi za hrvatski pravno-povijestni rečnik ова именица је наведена као посебна одредница, али уз коментар аутора да je „sjevernih stranah obična, a čuje se i u Slovenaca”, док је у ,južnih stranah hrvatskih" највероватније давно потиснута од такође псл. им. *brusъ (Мажуранић 1908: 846, s. v. osla). Другим речима, псл. им. *os(b)la у виду својих континуаната опстала је у кајкавском дијалекту, док ју је у чакавском и штокавском заменила истозначна псл. им. *brusъ, те отуда њени континуанти изостају у савременом српском језику, као репрезентанту тзв. штокавског, али су, како се претпоставља (в. Мажуранић 1908: 846, s. v. osla; ECCJA 36: 85 , s. v. *os(b)la), траг могли оставити у топонимији. Познато је, наиме, да је топономастичка грађа драгоцен извор за проучавање старе апелативне лексике,

${ }^{12} \mathrm{O}$ секундарној афиксацији у старословенском језику в. у Јефимова 2006: 18-21.

${ }^{13}$ Упор., на пример, Бошковић 1978: 367.

${ }^{14}$ Истокорене паралеле псл. именици *os(b)la 'брус, тоцилни камен (тоцило)' (упор. стсл. oсла, цсл. осьла) присутне су у многим другим ие. језицима (упор. ствнем. ahil 'оштрица, бодља', јерм. asetn, astan 'игла', англосакс. egl 'оштрица, трунка (у оку)', енгл. ails 'оштрица, бодља', сткимр. ocoluin 'брус', лат. aculeus 'убод' (Покорни 1959: I, 18, s. v. 2. ok-, ak-; ECCJA 36: 84-86, s. v. *os(b)la; ЕСБM 1: 175, s. v. Асла'), те ју је, сходно томе, основано сматрати пие. наслеђем у прасловенском. Међутим, другачијег је мишљења М. Сној (2016: 504, s. v. ósla), који сматра да је она, попут именица типа *metъla или *tesla, изведена од псл. глагола са значењем 'брусити, оштрити', такође пореклом из пие. коренског гнезда $* h, e k$ '-, међутим ишчезлог током историјског развитка словенских језика.

${ }^{15}$ У РСАНУ, на пример, ова лексема није потврђена. 
нарочито оне која се током времена може изгубити односно престати јављати у самосталној употреби.

3) Будући да је на синхроном пресеку у коме је забележен разматрани ороним посведочено немало топонима истоветне структуре чија је придевска основа пореклом од фитонима, и кад је реч о основи $o s(b) l b n$ - не би требало искључити ни ту могућност. Наиме, у српском језику постоје називи за различите биљне врсте чији је корен осл- $(<$ псл. *os-(b)l-). Заједничка фитоморфолошка особеност тих биљака са истокореним називима јесте то што имају имају оштре, бодљикаве односно длакаве листове: упор. осленица 'видац (Euphrasia officinalis), биљна врста из породице воловотки (Orobanchaceae), чији су листови длакави и тестерасто назубљени' (Симоновић 1959: 626; РЈА3У IX: 218. s. v. 2. oslenica), као и ошлак/ошљак '(њивска) паламида (Cirsium arvense), са упадљиво бодљикавим листовима' (Симоновић 1959: 627, s. v.) или „neki osobiti ječam” (РЈАЗУ IX: 323, s. v. 1. ošlak).

Биљна врста Cirsium arvense (нар. ошлак/ошљак), заједно са биљним врстама Cirsium eriophorum (нар. магариње, магариш, оста) и Onopordon acantium (нар. магарећи трн, магарећи чкаљ, ошљи обад) потиче из породице главочика (Asteraceae), препознатљивим (између осталог) по шиљатим, бодљикавим листовима. За именовање биљних врста из породице главочика типа магарећи трн, магарећи чкаљ, ошььи обад (упор. осао 'магарац'), те и магариње, магарии - највероватније је био пресудан облик њихових листова који је номинатора могао подсећати на магареће шиљате уши. Међутим, ваља истаћи да фитоними ошљак и ошлак (Cirsium arvense) не морају искључиво бити у етимолошкој вези са им. осао (< псл. *osblb), већ потицати од псл. *os-(b)l- чији деривати носе семантику оштрине, бодљикавости (упор. псл. им. *os(b)la 'брус, тоцилни камен (тоцило)'). ${ }^{16}$ Мотивацију за назвање биљке према њеној упадљивој физичкој особености као што су бодљикави односно длакави листови потврђују многобројни фитоними са кореном ос- односно ocm- (< псл. *os-(bt)-/*ost-, пореклом из пие. *h $e k$ '-). Навешћемо неке од њих: осав 'овас (Avena)' (упор. и оs „,bodlika na klasu” (PJA3У IX: 183. s. v. 3. os), као и nomina collectiva osje (PJA3У IX: 198. s. v.)); осад 'драч(a), листопадна жбунаста биљка препознатљива по мноштву бодљи по стаблу и изданцима (Paliurus aculeatus)'; осак 1. 'орањ, зељаста биљка са длакавом стабљиком и назубљеним листовима (Chamaeplium officinale)', 2. Sisymbrium, S. Sophia; ocam 'биљке из родова породице главочика (Asteraceae) препознатљиве по бодљикавим листовима: 1. Carduus (C. acanthoides), 2. Cirsium (C. arvense, C. lanceolatum) и 3. Serratula' (упор. псл. *osъtъ 'биљка Carduus, боца, бели чкаљ' (ECCJA 36: 77, s. v.)); осатицуа (Bromus ramosus); осатка 1. 'попино

${ }^{16}$ Beћ je у РЈАЗУ (IX: 323, s. v., 1), под одредницом ošlak, указано на дилему у вези са тим да ли је овај фитоним у етимолошкој вези са им. осао 'магарац' или са им. ос 'бодљика на класу'. 
прасе, јечам (Hordeum murinum, H. secalinum), биљке са крхким шиљцима', 2. 'мачији реп (Phleum pretense), влатаста трава са листовима по ивици храпавим и постепено суженим при врху'; осет питоми 'артичока (Cynara scolymus), са издуженим и назубљеним листовима' (Симоновић 1959: 626, s. v.); остак 'биљне врсте из родова породице главочика (Asteraceae): 1. Cirsium (Cirsium arvense) и 2. Sonchus (S. arvensis, S. oleraceus); остан (Cirsium) (Симоновић 1959: 626). ${ }^{17}$

Ниско бидљикаво растиње типично је за брдско-планинско подручје (на пример, познато је да поменута осленица 'видац (Euphrasia officinalis)' расте на пашњацима и шумским чистинама од брдских до алпских предела). Стога није искључено да је предео односно рељефни објекат именован као ос(ь)дьннкь био прекривен бодљикавим биљем, што је могло бити пресудним за његово именовање. Да је такво тумачење мотивације оправдано, потврђују и поједини топоними на (старо)српском говорном простору који су изведени од народних назива за биљну врсту Carduus (acanthoides) (нар. осат, водени осат): упор. у Бањској хрисовуљи забележен синтагматски назив (сьт'на ннва, у коме је фитоним ocam (< псл. *osъtъ 'биљка Carduus, боца, бели чкаљ') потврђен преко свог деривата прид. *osъtьnъ (Лома 2013: 164, s. v. ОСЬТНА ЊИВА); затим ојконим Осатица, као и хидроним Осатички поток (Павловић 1994: 99, s. v.).

\section{4. ПОТВРДЕ У ШИРЕМ ЛИНГВОГЕОГРАФСКОМ КОНТЕКСТУ}

Топонимијска формација ос(ь)льннкь забележена је и у другим старосрпским изворима, тј. и у неким другим лингвогеографским контекстима, што говори о продуктивности датог творбеног обрасца и датог мотивационог модела на ширем простору тадашњег српског језика. У наставку ћемо навести потврде из нама доступних извора.

а) Ојконимијска формација осьльннкь потврђена је у Хрисовуљи краљь Стефана Уроша I манастиру Св. апостола Петра и Павла на Лиму (око 1252): $\mid{ }^{109}[\ldots]$ ( како сє камы валы оү Грьдань доль (ЗСПП: 230) и Хрисовуљи краља Стефана

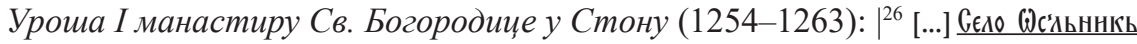
or Прнморн (ЗСПП: 196). Наведене ојкониме нисмо успели да идентификујемо у другим историјским изворима, као ни на савременим картама одговарајућих географских подручја.

${ }^{17}$ Упор. и одговарајуће примере из РЈАЗУ (IX): osak (183, s. v.), osjak „ime biḷama” (198, s. v.), као и територијалне називе за особиту врсту шљиве: oslača $(215$, s. v.), oslica (219, s. v., 3$)$, оs̆lıča (323, s. v., 2) и сл. 
б) Ојконимијску формацију осьльннкь налазимо и у нешто доцнијем извору - у Повељи босанског краља Стефана Остоје Дубровнику (1399. год.): (әсальннкь, село у залеђу Дубровника (РКС: II, 243, s. v. осьльннкь; МС: 234). Овом дубровачком селу, по свему судећи, данас одговара насеље познато под именом Осојник (в. РЈАЗУ IX: 188, s. v. OSAONIK). На преосмишљавање примарног назива - поред регуларних историјских гласовних процеса: Osblbnikъ $>$ Osblnik (испадање полугласника у слабој позицији) > Osaonik (вокализација полугласника у јакој позицији и прелазак $l$ у $o$ на крају слога) $>O s \bar{n} i k$ (асимилација и сажимање самогласника) - утицало је, како претпоставља В. Мажуранић (1908: 846-847, s. v. Oslnica), прилагођавање „drugoj osnovi slična zvuka: umesto osal ili osla, što je moglo biti poreklo mesnom nazivu, pomislilo se na ino postojanje, od osnove osoje (locus opacus) i veze sa suncem". Наиме, деетимологизација првобитног назива - узрокована како током историје одиграним гласовним процесима, тако и ишчезавањем континуаната псл. им. *os(b)la на штокавском говорном простору - утицала је, како претпостављамо, на народно етимологизирање и довођење у везу овог назива са продуктивном топонимском основом osoj- (< псл. дијал. *otъsoje 'место окренуто од сунца'), заступљеном широм (старо)српског говорног простора (в. Лома 2013: 165, s. v. ОСОЈАНИ).

в) Код села Плочице општине Конавле, недалеко од Дубровника, постоји још један Осојник - брдо локалном становништву познато и као „конавоска пирамида". Конавоски ороним Осојник, будући да је у 15 . веку забележен у облику „OSAONIK” (Капетанић 2011: 160, карта, према Тројановић 2015: 31), претпрпео је највероватније исти гласовни развитак и преосмишљавање назива као и дубровачки ојконим Осојник. Територија Конавала је позната по остацима тумула, камених хумки, карактеристичних за културу илирских племена која су до пред крај старе ере масовно живела на том подручју. Тумули утицајнијих Илира могли су бити нарочито високи, а за неке од њих се претпоставља да су функционисали и као светилишта. Зидови од наслаганог камена, тзв. сухозиди - који су делом илирско наследство, а делом плод рада динаридског тежака који је слагањем камена обезбеђивао себи простор за садњу - културно су обележје читаве далматинске територије и уједно потврда значаја древног каменитог крајолика за њену материјалну културу (в. фотографије Осојника у Тројановић 2015: 32-36).

Сагледавајући топономастички контекст - остатке илирске градине на врху Осојника, бројне сухозиде, те и пирамидални облик овог претежно каменитог брда - сматрамо да је основано претпоставити етимолошку, те и мотивациону везу разматраног оронима са псл. им. *os(b)la 'брус, тоцилни камен (тоцило)'. Конавоски ороним Осојник (у 15. веку: „Osaonik”), наиме, највероватније је настао суфиксалном универбизацијом писано непосведочене синтагматске номинације типа **os(b) lbni brěgъ. За такво назвање номинатор је могао бити мотивисан како изразитом заступљеношћу (оштрог) камена на 
номинованом рељефном објекту, тако и његовим пирамидалним обликом. Узгред, да није тако, не би га ни данас локално становништво звало конавоском пирамидом.

Ојконимска формација осьљьннкь забележена у Хрисовуљи краља Стефана Уроша I манастиру Св. апостола Петра и Павла на Лиму, Хрисовуљи краља Стефана Уроша I манастиру Св. Богородище у Стону и Повељи босанског краља Стефана Остоје Дубровнику, према нашем мишљењу, у сва три случаја могла је, такође, бити мотивисана каменитим (**oc(a)лним) деловима сеоске територије или пак изразито зашиљеним рељефним објектима - по којима је, због њихове упадљивости, читаво село могло добити име.

\section{1. Значај ширег лингвогеографског контекста за мотивациону реконструкцију доњополошког оронима ос(ь)дьннкь}

Примарну мотивацију доњополошког оронима ос(ь)дьннкь - који, заједно са идентификованим Нановим долом, припада шарпланинском комплексу над Тетовом - могли бисмо објаснити на истоветан начин. Иако Шаром доминирају пашњачки предели, ову планину одликују и камените површине - како у виду камених гомила тј. брежуљака, тако и у виду равних површи и увала засутих каменом - које, спорадично пресецајући доминантне травнате површине, уједно бивају упадљивијим. Сматрамо да би разматрани ороним ос(ь)льннкь управо могао означавати једну такву камену површину у суседству травнатом Нановом долу или пак брдо (можда и стену) нарочито заоштрену при врху.

Ако је заиста тако, разматрани доњополошки и поменути конавоски ороним могли би почивати на истоветној мотивацији. При томе, значајно је поменути да у томе не би били усамљени будући да је планина Осла (рум. Muntele Oslea) у Ердељу (румунском делу Баната, где и данас живи словенски живаљ), према мишљењу Ф. Миклошича (1874: 70, s. v. osla), понела име управо по словенском називу за 'брус' - псл. *os(b)la.

\section{5. ЗАКљУЧНА РАЗМАТРАЬА}

На основу спроведене етимолошко-ономасиолошке односно творбено-семантичке анализе доњополошког оронима ос(ь)дьннкь - по питању његове изворне мотивације можемо изнети неколико закључака. Најпре, позивајући се на познате творбене законитости, одбацили смо могућност да придевска основа $o s(b) l b n$ - потиче од им. *osblb 'магарац' будући да се придеви са суфиксом -ьпъ од зоонима изводе само по изузетку, те и да придев **osblbnъ 'магарећи' у прасловенском није могуће реконструисати. Сагледавањем топонимијске грађе на синхроном пресеку од краја 12. до почетка 14. века установили смо 
да је образовање топонима универбизацијом - при којој се на придевску основу зависног члана претпостављене примарне синтагматске номинације додавао суфикс -ikъ - на датом језичком пресеку било продуктивно. Према нашем увиду у старосрпску грађу тог периода, највећи број овако грађених топонима био је у мотивационој вези са фитонимима карактеристичним за дати локалитет (упор. Хвонннкь, Брєсннкь, Сирьз'ннкь / Смргячнннкь и сл.). Сходно томе, указали смо и на теоријску могућност по којој би основа $o s(b) l b n$ - била у мотивационој вези са истокореним називима за биљне врсте упадљиве по својим оштрим, зашиљеним, бодљикавим листовима. Међутим, нисмо дубоко уверени у то колико би бодљикаво ниско растиње било пресудно за номинацију датог планинског предела. Бодљикавог биља може бити по читавој планини и по пашњацима, и међу камењем - те је диференцијални потенцијал овакве ономасиолошке основе невелик, а дистинктивна функција овако мотивисаног назива незнатна.

Претпоставка према којој се доњополошки ороним ос(ь)льннкь доводи у етимолошку, те и мотивациону везу са псл. им. *os(b)la 'брус, тоцилни камен (тоцило)', према спроведеном истраживању, показала се као најверодостојнија, будући да је оправдана како са становишта унутарјезичких законитости, тако и са становишта ванјезичког контекста. На тај начин означени рељефни објекат у перцепцији номинатора највероватније је био упадљив по својој изразитој зашиљености, довољно истакнутој да га индивидуализује односно разликује од других (можда и сличних) околних објеката. Додуше, не можемо у потпуности одбацити ни могућност да је за именовање датог рељефног објекта била пресудна прекривеност ослом, заоштреним каменом од кога су се могли израђивати брусеви или који је био налик таквом, због чега је међу доминантно травнатим површинама био нарочито истакнут.

\section{1. Даљи правци испитивања (старо)српске топонимије}

Сматрамо да би спроведено истраживање могло бити од значаја у етимолошко-ономасиолошким тумачењима (старо)српских топонима блиске творбене струкуре. На пример, савремено жагубичко насеље Осаница (Хомоље) у 14. веку је посведочено у два гласовно-графијска лика - Осаннца и Осльннца (РКC: II, 243, s.v. осьльннца), као село које је кнез Лазар даровао браничевском манастиру Ждрело (МС: 194). Судећи по томе, гласовни развитак овог браничевског ојконима налик је раније представљеном развитку дубровачког Ocojника: упор. Osblbnica > Osblnica (губљење полугласника у слабој позицији) > Osaonica (вокализација полугласника и прелазак $l$ у o) $>$ Osanica (прогресивна асимилација и сажимање самогласника). Ојконим Осаница на територији Р. Србије налазимо још на подручју новопазарске и трстеничке општине, док на подручју Ивањице бележимо ојконим Осонииу, са претпостављеном вокалском 
асимилацијом истог смера као код дубровачког Осојника. ${ }^{18}$ Посебно место у испитивању имена која се етимолошко-ономасиолошком анализом могу свести на псл. корен *os- - заузимали би и хидроними попут јагодинске речице Осаонице, словен. реке Osilnice и сл. ${ }^{19}$

Наведени топоними несумњиво изискују засебна етимолошко-ономасиолошка испитивања, што остављамо за нека будућа трагања, надајући се, притом, да смо овим радом дали свој мали допринос великој и значајној теми етимолошке реконструкције наше историјске топонимије.

\section{ИЗВОРИ И РЕЧНИЦИ}

АСАНУ: Краљ Стефан Урош II Милутин обнавља манастир св. Горга у Скопљу, Архив САНУ, 7903-a/6а, б, в, г (фотографија).

Безлај 1961: F. Bezlaj, Slovenska vodna imena, II. del (M-Ž), Ljubljana: Slovenska akademija znanosti in umetnosti.

Дерксен 2008: E. Derksen, Etymological Dictionary of the Slavic Inherited Lexicon, Leiden-Boston: Brill, 2008.

Грујић 1936: Р. Грујић, Три хиландарске повеље, у: Р. Грујић (ур.), Зборник за историју јужне Србије и суседних облати, књ. 1, Скопље, 1-26.

Грујић 1933: Р. Грујић, Полошко-тетовска епархија и манастир Лешак, Гласник СНД, 12, 33-77.

ЕСБМ 1 (1978): Этыммалагічны слоўнік беларускай мовы, т. 1 (рэд. В.У. Мартынаў), Мінск: Навука і тэхніка.

ЕССЈА 36 (2010): Этимологический словарь славянских языков. Праславянский лексический фонд, Выпуск 36 (ред. А. Ф. Журавлев), Москва: «Наука».

ЗСПП (2011): Зборник средњовековних ћириличких повеља и писама Србије, Босне и Дубровника, књига 1, 1186-1321, прир. В. Мошин, С. Ћирковић, Д. Синдик, Београд: Историјски институт Београд.

${ }^{18}$ Поред тога, сматрамо да би у етимолошка тумачења оронима Ошљак, заступљеног широм српског говорног подручја (в. Павловић 2015: 365, s. v. ОШљАК), требало укључити и претпоставку по којој би овај ороним могао бити и у етимолошкој вези са псл. им *os(b)la 'брус, тоцилни камен (тоцило)'. Упор. и несоним Ошљак, острво у Јадранском мору.

${ }^{19}$ Дотичући се ьихове етимологије, Ф. Безлај (1961: 65-66, s. v. OSILNICA) преноси Миклошичево мишљење по коме би оне могле бити у етимолошкој вези са псл. им. *os(b)la, али уз то наводи и фитоним osilnica (Oxytropis), за који истиче да се вероватно може свести на исти псл. корен. 
Иванов 1970: Й. Иванов, Български старини из Македония, фототипно издание на издание от 1931 (ред. Б. Ангелов и Д. Ангелов), БАН: Наука и изкуство.

Копривица 2014: М. Копривица, Хрисовуља краља Стефана Душана Хтетовском манастиру, Стари српски архив, књ. 13, 143-179.

Лома 2013: А. Лома, Топонимија Бањске хрисовуље. Ка осмишљењу старосрпског топономастичког речника и бољем познавању општесловенских именских образаца, Београд: САНУ, Одељење језика и књижевности, Одбор за ономастику, Библиотека Ономатолошких прилога, књ. 2.

Капетанић 2011: N. Kapetanić, Konavle u XV. stoljeću, Gruda: Matica hrvatska, Ogranak Konavle.

Мажуранић 1908: V. Mažuranić, Prinosi za hrvatski pravno-povijetsni rječnik, Zagreb: JAZU.

Миклошич 1874: F. Miklosich, Die slavischen Ortsnamen aus Appellativen II, Wien: Gerold.

MC (1958): Monumenta serbica : Spectantia historiam Serbiae Bosnae Ragusii (edidit Fr. Miklosich), Viennae: Apud Guilelmum Braumüller.

Павловић 1994: 3. Павловић, Хидронимски систем слива Јужне Мораве, Београд: Институт за српски језик САНУ.

Павловић 2015: 3. Павловић, Ороними Србије. Део 2 (К-П), Ономатолошки прилози, књ. 22, 99-430.

Покорни 1959: I. Pokorny, Indogermanisches etymologisches Wörterbuch, I. Band, Bern - Münich: A. Francke.

PJA3У IX (1924-1927): Rječnik hrvatskoga ili srpskoga jezika (ur. T. Maretić), tom IX, Zagreb: Jugoslavenska akademija znanosti i umjetnosti.

РКС (1863-1864): Ђ. Даничић, Рјечник из књижевних старина српских, I-III, Биоград: Државна штампарија.

Симоновић 1959: Д. Симоновић, Ботанички речник научних и народних имена биљака са именима на руском, енглеском, немачком и франиуском језику, Београд: Научно дело.

Сној ${ }^{32016: ~ M . ~ S n o j, ~ S l o v e n s k i ~ e t i m o l o s ̌ k i ~ s l o v a r, ~ L j u b l j a n a: ~ I n s ̌ t i t u t ~ z a ~ s l o v e n s k i ~}$ jezik Frana Ramovša ZRC SAZU.

Спом.III (1980): Спомениичи за средновековната и поновата историја на Македонија, Том III: Грамоти, записи и друга документарна граѓa за манастирите и црквите во полошка област и соседните краеви, 
подготвиле Лидија Славева и Петар Миљковиќ (ур. Владимир Мошин), Скопје: Архив на Македонија.

Станковска 1983: Љ. Станковска, Македонскиот топонимски систем до XVI век, рукопис докторске дисертације, Скопје.

СС (1994): Старославянский словарь, по рукописям X-XI веков, Р. М. Цейтлин, Р. Вечерка, Э. Благова (ред.), Москва: Русскый язык.

Тројановић 2015: A. Trojanović, Interpretacija kulturnog krajobraza Konavala, završni rad odbranjen naAgronomskom fakultetu Sveučilišta u Zagrebu, $<$ https://docplayer.rs/139128639-Sveu\%C4\%8Dili\%C5\%A1te-uzagrebu-agronomski-fakultet-studij-krajobrazne-arhitekture-anitatrojanovi\%C4\%87-interpretacija-kulturnog-krajobraza-konavalazavr\%C5\%A1ni-rad-zag.html>. 1. 10. 2020.

\section{ЛИТЕРАТУРА}

Божанић 2011: С. Божанић, Ороними у српским средњовековним повељама: њихов помен у функцији пограничног ентитета простора, Истраживања 22, 117-130.

Бошковић 1978: Р. Бошковић, Одабрани чланщи и расправе, Посебни радови, књ. 1, Титоград: Црногорска академија наука и умјетности.

Вучковић 2017: С. Вучковић, Повест словља : Историјсколексиколошка истраживања, Београд: Филолошки факултет.

Јефимова 2006: В. С. Ефимова, Старославянская словообразовательная морфемика, Москва: Институт славяноведения РАН.

Лома 2013: А. Лома, Топонимија Бағске хрисовуље. Ка осмишљену старосрпског топономастичког речника и бољем познавању општесловенских именских образаиа, Београд: САНУ, Одељење језика и књижевности, Одбор за ономастику, Библиотека Ономатолошких прилога, књ. 2.

Мишић 2007: С. Мишић, Међе у Светостефанској хрисовуљи, Манастир Бањска и доба краља Милутина : зборник са научног скупа одржаног од 22. до 24. октобра 2005. године у Косовској Митровичи, Ниш - Косовска Митровица - Манастир Бањска, 43-53.

Пурковић 1940: М. Пурковић, Одређивање међа, Етнологија, год. I, св. 2, 65-84.

Труфуновски 1976: Ј. Трифуновски, Полог (антропогеографска проучавања), у: О. Благојевић (ур.), Српски етнографски зборник, књига 42, Београд: САНУ. 
Трубачов 2008: О. Н. Трубачев, Труды по этимологии : Слово. История. Культура, Том 3, Москва: Рукописные памятники Древней Руси.

\section{OLD SERBIAN ос(ь)лннкь: WORD FORMATION AND MOTIVATIONAL RECONSTRUCTION}

\section{Summary}

Based on the conducted etymological-onomasiological and word-formation analysis of the Lower Polog oronym oc(b)льннкь, regarding its primary motivation in the paper, several conclusions are presented: (1) we have rejected the possibility that the os(b)lbn-comes from Proto-Slavic noun *osbl 'donkey' since adjectives with the suffix - $b n$ b originated from zoonyms in Proto-Slavic were derived only by exception; (2) we have pointed out the theoretical possibility according to which the basis $o s(b) l_{b n}$ - would be in a motivational connection with the cognate names for plant species conspicuous by their sharp and pointed leaves; (3) the assumption according to which the Lower Polog oronym ос(ь)дьннкь is brought into an etymological connection with Proto-Slavic noun *os(b)la 'hone, grinding stone (whetstone)' is singled out as the most credible, since it is justified both from the point of view of intralinguistic rules and from the point of view of the extralinguistic context. Namely, for the nomination of the relief object most likely the decisive factor was its distinct sharpness or being covered with sharpened stone from which the whetstones could be made or which was like it.

Keywords: historical toponymy, historical oronymy, Old Serbian language, motivational reconstruction, Polog. 